\title{
HUMANISMO, HISTORIA Y REVOLUCIÓN EN EL JOVEN MACINTYRE*
}

\author{
HUMANISM, HISTORY AND REVOLUTION IN YOUNG \\ MACINTYRE'S THOUGHT
}

Rafael Ramis Barceló

Recibido: enero de 2011.

Universidad Pompeu Fabra

Aceptado: marzo de 2011

Palabras clave: MacIntyre, humanismo, historia, revolución, marxismo.

Keywords: Maclntyre, humanism, history, revolution, marxism

Resumen: Este artículo trata de mostrar la evolución intelectual de Alasdair Maclntyre de 1958 a 1960 . Con este fin, se resumen las ideas de Maclntyre en el contexto de la ideología de izquierda en Gran Bretaña, principalmente en la recepción del estalinismo ortodoxo, y su crítica de acuerdo a la revisión de los intérpretes de Marx: Lenin, Trotsky, Lukács y Kautsky. El artículo trata de explicar tanto la evolución política como la intelectual de MacIntyre (New Left, Socialist Labour League, Socialist International), de acuerdo con tres problemas principales: el humanismo, la historia y la revolución.

Abstract: This article tries to show the intellectual evolution of Alasdair Maclntyre from 1958 to 1960 . For this purpose, it summarizes the ideas of MacIntyre in the context of the left ideology in Great Britain, mainly the reception of the orthodox Stalinism, and his criticism according to the revision of Marx interpreters: Lenin, Trotsky, Lukács and Kautsky. The article tries to explain both the political and intellectual evolution of MacIntyre (New Left, Socialist Labour League, Socialist International) according to three main problems: humanism, history and revolution.

Estoy en deuda con los profesores Josep Maria Vilajosana, Víctor Méndez Baiges y Amelia Valcárcel, que leyeron una primera versión de este artículo y formularon agudas observaciones. 
Maclntyre, al igual que otros profesores universitarios, abandonó el Partido Comunista Británico después de los sucesos de Octubre de 1956 en Hungría. La indecisión y frialdad de los Partidos Comunistas europeos enalteció los ánimos de los que, como él, pensaban aún en la posibilidad de un comunismo «con rostro humano». El filósofo escocés había empezado en 1948 su singladura en ese partido de la mano de George Thompson, su profesor de Griego, aunque desde el primer momento se había mostrado crítico y reticente con las formas autoritarias de la URSS.

En este trabajo pretendo explicar cuáles son las reacciones intelectuales de Maclntyre frente a las ideas de los teóricos del «socialismo real» (en particular Stalin) así como su posición dentro de la New Left, antes de pasar en 1960 a la Internacional Socialista, de filiación trotskysta. El momento que pretendo analizar es, por tanto, bastante breve, pues se ocupa solamente del lapso entre 1958 y $1960^{1}$.

Ésta fue una época fértil en la que Maclntyre tuvo que posicionarse, principalmente, en tres direcciones: a) la crítica al «marxismo» de Stalin y, en particular, su Filosofía de la Historia, b) las consideraciones acerca del «humanismo marxista» antiestalinista promovido por Thompson en los debates en el seno de la Left Review, y c) un análisis hermenéutico acerca de la verdadera vocación revolucionaria del pensamiento de Marx. Estas cuestiones determinan los puntos que voy a examinar a lo largo de este escrito.

\section{El marxismo, el estalinismo y el problema de la historia}

Maclntyre, desde comienzos de la década de los cincuenta, tenía en su reflexión dos inquietudes fundamentales (marxismo y cristianismo) como ejes de la Historia occidental. De hecho, su libro Marxism: An interpretation ${ }^{2}$ es un intento de acercar la dimensión escatológica del cristianismo a la profecía marxista de la superación del capitalismo. La preocupación por la historia es, desde ese momento, una cuestión insoslayable en la obra de Maclntyre.

En ese libro se dibujaron por primera vez algunos de los problemas más relevantes que la doctrina marxista planteaba al escocés. Su postura crítica -con un pie en los Evangelios y otro en los Manuscritos de Economía y de Filosofíadesconfiaba de la praxis de quienes se declaraban continuadores de los proyectos escatológicos propuestos en estos libros. De hecho, cuando Maclntyre decidió romper con la New Left y con la Socialist Labour League (SLL) confesó también que no podía continuar siendo cristiano. La praxis marxista y el cristianismo eran elementos que, en el joven Maclntyre, se daban simultáneamente.

Como se verá en las próximas páginas, el desgaste de uno conllevó el deterioro del otro. La época que abarca desde 1956 hasta 1960 representó, pues, la crítica y revisión continua de ese proyecto existencial trazado en Marxism: An interpretation sobre unas bases inestables cuya conjunción Maclntyre deseaba con mayor vehemencia que raciona- 
lidad ${ }^{3}$. La «revisión»-desde un prisma historicista- del cristianismo fue una cuestión siempre esbozada, aunque nunca acabada. De hecho, el cristianismo al que Maclntyre continuaba adherido quedó muy depurado -e incluso vaciado- después de sus análisis lingüísticos al calor de la Filosofía de la religión de Oxford 4 .

Si el cristianismo había permanecido en el «imaginario» de Maclntyre en una versión muy debilitada, que sólo se aguantaba por criterios de un historicismo casi hegeliano, su marxismo pasó también por una depuración igualmente radical. El acontecimiento histórico que supuso el espoleo definitivo hacia una crítica del marxismo fue, como ya he apuntado, la indecisión de los Partidos Comunistas frente a las atrocidades perpetradas por el Ejército Rojo en Budapest, así como también su opacidad en la transmisión de la información.

El escocés no se puso a escribir directamente sobre esos sucesos, pero sí repensó implacablemente el devenir histórico del llamado «socialismo real» $»^{5}$. Por de pronto Maclntyre, al igual que muchos intelectuales británicos, dejó el Partido Comunista Británico y se alejó claramente de la ideología soviética. Si en Marxism: An interpretation, Maclntyre se había mostrado crítico con la teoría historicista de Stalin pero no había roto completamente con las tendencias revisionistas del "comunismo ortodoxo», a partir de 1956 se mostraría refractario hacia cualquier tipo de revisionismo y, sobre todo, hacia la teoría estalinista de la historia.

\section{l.l. Los antecedentes}

Muchas de estas críticas ya estaban presentes en 1953: fundamentalmente, la crítica a la concepción histórica de Lukács y Kautsky, así como, más acerba, a la de Stalin. Según MacIntyre, Lukács representaba el idealismo y la confianza en el Partido Comunista, pues «la verdadera conciencia proletaria» se encarnaba en el Partido Comunista, que recogía el legado de Marx y que definía su existencia en términos marxistas. Al hacerlo, el partido se convertía en un "agente de la historia», encargado de abrir el futuro al movimiento proletario ${ }^{6}$.

Frente al subjetivismo de Lukács, Maclntyre contrapuso el objetivismo «heterodoxo» de Kautsky, que recogía algunas ideas del evolucionismo de Engels. Stalin acabó tomando mucho más del «heterodoxo» Kautsky que del "oficialista» Lukács, y su concepción acabó apelando a la inexorabilidad de la historia. Los elementos mecanicistas y deterministas fueron amplificados en su máxima expresión, de modo que la teoría histórica de Stalin -que él atribuía originariamente a Marx- podía pasar por objetiva y científica. Indirectamente, dicha teoría de la historia era una manera muy cómoda a partir de la cual se podían justificar las mayores arbitrariedades $^{7}$.

Por otra parte, ese debate sobre la dimensión histórica era calcado al que la Iglesia había fabricado para su propia legitimación. Maclntyre, cuando escribía sobre el marxismo, miraba de reojo la legitimación de la Iglesia católica apostólica romana. ¿Por qué apoyar tan de- 
cididamente unas construcciones ideológicas hechas sobre bases tan oscuras?

Realmente, el problema que trataba MacIntyre tenía un calado aún mayor: el problema no era sólo de filosofía de la historia, sino también de orden epistemológico. Ya desde la juventud, el escocés estuvo convencido de que los suyos eran tiempos de miseria intelectual y moral. No existían «razones para la acción», de modo que era imposible articular un discurso teórico que a la vez integrara una praxis.

MacIntyre había estudiado con profundidad el proceso de la Modernidad: no sólo Hegel y Marx, sino también Kant y Hume. Estos autores representan la gran fractura entre la teoría y la praxis (o entre el is y el ought en el caso de Hume, - la Razón Pura y la Razón Práctica, en Kant ${ }^{8}$ ). En su primer libro, el escocés vio claramente que el proyecto de la Modernidad sólo podía salvarse a través de la secularización del cristianismo en una Filosofía de la Historia. El eje Hegel-Marx representaba ese afán secularizador, que bañaba nuevamente en las aguas de la Historia al sujeto escindido por la llustración ${ }^{9}$.

Lo que MacIntyre no acababa de ver claro es que el cristianismo quedara tan secularizado en manos de Hegel o de Marx, sino que esa religión, en tanto que movimiento ideológico, continuaba viviendo escatológicamente en el marxismo. E incluso, tal y como lo interpreto, el joven Maclntyre creía que el marxismo renovaba hasta cierto punto el compromiso escatológico del cristianismo, de suerte que era un complemento «material» de una religión que ponía sus me- tas históricas en lo sobrenatural. En todo caso, lo que está fuera de debate es que marxismo y cristianismo eran para Maclntyre dos fenómenos ideológicos perfectamente compatibles ${ }^{10}$.

Dicho lo anterior, creo que puede contestarse ya a la pregunta formulada un poco más arriba acerca de las oscuras bases intelectuales: MacIntyre no tenía más remedio que "confiar» en el cristianismo y en el marxismo, como formas de superación del sujeto escindido de la Modernidad. Es en este sentido que el escocés pasa por encima de los oscuros orígenes del movimiento marxista y del cristianismo para poner el acento no tanto en la Parusía como en la construcción del «Reino de Dios» y de la «Sociedad sin clases», de modo que ambas corrientes tuvieran un proyección histórica terrenal.

Superada esta primera objeción, el marxismo se debatía entre la subjetividad de la voluntad grupal de la clase trabajadora -constitutuida en el Partido Comunista- que se encarnaba en la Historia como agente histórico del sentir obrero (Lukács) y las leyes del materialismo dialéctico de Engels, que conducían inexorablemente hacia la desaparición de las clases, llevándose también por delante a cuantos enemigos del Partido fuesen necesarios para establecer ese «alto» fin (Stalin). El cristianismo también se encarnaba en la Historia como el cuerpo místico de los creyentes en Jesús resucitado, el Hijo de Dios Padre, (la Iglesia) que, peregrinantem in terra, era guiada por el Espíritu Santo hacia la realización plena del Reino de Dios, que acabaría en la Parusía ${ }^{11}$. 


\subsection{Stalin y la teoría de historia}

Josef Stalin se aprovechó de las teorías deterministas para encarnarse en el brazo ejecutor de ese "desarrollo» imparable. Fundiendo las aportaciones partidistas de Lukács con el objetivismo mecanicista de Kautsky, Stalin intentó revestir sus operaciones políticas con una aureola científica. Dicha operación intelectual mostraba principalmente dos aspectos: una justificación históricoteorética y una explicación mecánicopráctica.

Comentando estas ideas, MacIntyre participó en los debates que se realizaron para conformar la New Left review, que fundía dos revistas: Universities Left Review y The New Reasoner. Su contribución a la primera revista, que debía marcar la tendencia a seguir por parte de la New Left, se concretó en dos comentarios: 'On Not Misrepresenting Philosophy12" y "The Algebra of the Revolution ${ }^{13}$ ", a los que aludiré más adelante.

Edward Thompson abrió un debate en The New Reasoner ${ }^{14}$ sobre la naturaleza del marxismo de Stalin ${ }^{15}$, y tocó dos aspectos esenciales: la «teoría de la historia» y la posibilidad del "humanismo marxista» ${ }^{16}$. Me centraré aquí en la primera cuestión, y dejaré la segunda para el siguiente apartado.

Thompson describió la justificación histórico-teorética y la explicación mecánico-práctica de Stalin, pero regresó a la encrucijada entre el objetivismo o el subjetivismo que MacIntyre planteó en 1953. Para Thompson, en el estalinismo se producía una circunstancia ex- traña: por una parte, Stalin era el culpable de viles atrocidades, pero por otra, era el que había desarrollado la acción proletaria del materialismo histórico.

El segundo argumento de Thompson tenía dos dimensiones: la primera, la aceptación tácita de la que todas esas matanzas tenían que ocurrir, de modo que se cumplía el desarrollo de la Historia y la marcha hacia la sociedad sin clases; la segunda -aún más profunda- era que Stalin había puesto en práctica la interpretación del marxismo a partir del mecanicismo de la tradición de Engels y Kautsky.

The instruments of production in the Soviet Union are socialised. The bureaucracy is not a class, but is parasitic upon that society. Despite its parasitism, the wave of human energy unleashed by the first socialist revolution has multiplied the wealth of society, and vastly enlarged the cultural horizons of the people ${ }^{17}$.

En definitiva, Thompson se quejaba de los métodos brutales y represivos de Stalin, pero daba por supuesto que ésa -y no otra- era la forma inevitable de avance del materialismo histórico. Y, por si fuera poco, el estalinismo, pese a sus métodos, era el cumplimiento evolucionista -y neodarwiniano- de la adaptación al medio social, y el progreso científico de la Historia. La conclusión de Thompson parecía aceptar, a la postre, los dos aspectos fundamentales de la teoría de la historia de Stalin, pese a que, formalmente, nunca lo llegara a decir de forma abierta ${ }^{18}$.

El artículo de Thompson recibió dos respuestas críticas $^{19}$ : la de Harry Hanson y la de Charles Taylor. Hanson destacó en 
una carta abierta a Thompson ${ }^{20}$, escrita desde una perspectiva deontologista, que la estrategia de Stalin había sido la industrialización masiva de la URSS y que la consecuencia inevitable de ello había sido una pérdida de los derechos humanos por parte de los soviéticos. Sin embargo, Hanson presentaba también esa conculcación de los derechos humanos como una consecuencia casi kantiana de una situación necesaria ${ }^{21}$.

We ought to choose militancy, as by doing so we speed the advent of the classless society, when all the moral ultimates we have been keeping tucked away in our kit-bags while the battle is raging can be released in an atmosphere which will no longer turn them to dust and ashes. But while the battle does rage, class militancy is the only moral principle that is worth anything. As long as what we do contributes to the victory of the revolution, we can be satisfied that it is right ${ }^{22}$.

Por su parte, Taylor ${ }^{23}$ consideraba que si el estalinismo había sido la metamorfosis del comunismo marxista, cualquier crítica al estalinismo lo era a la vez del comunismo marxista. El artículo intentaba defender el marxismo, pretendía una crítica del estalinismo y, por ende, de todo comunismo marxista, por no apoyarse en el humanismo de Marx. Sin embargo, cometía una falacia, pues equiparaba el estalinismo con la manifestación práctica del comunismo, de modo que se llegaban a confundir. Así, por tanto, el bienintencionado escrito de Taylor no se enfrentaba completamente al Partido Comunista, sino que era una matización a la contribución de Thompson.

\subsection{La respuesta de Maclntyre}

Siguiendo la línea de Taylor, el artículo de MacIntyre fue, sin duda, más violento, pues recogía y reprobaba todas las opiniones anteriores, en un trabajo profundamente crítico con el estalinismo. El escocés se encargó de desmontar a paso de carga tanto la encrucijada entre el objetivismo y el subjetivismo en el marxismo como también la doble proyección de la teoría de la historia del estalinismo.

La contribución de Maclntyre tenía tres frentes: a) el planteamiento del problema del divorcio entre hechos y valores o deseos (is/ought) en la teoría de la historia de Stalin, y el posible recurso a Aristóteles o a la filosofía griega para superarlo, b) la crítica del consecuencialismo de Thompson y del deontologismo de Hanson, y c) la reafirmación en el gran valor del historicismo de Marx, y en contra de los diferentes marxismos.

En el primero, MacIntyre recalcó que el estalinismo, al igual que hacía la filosofía moderna desde Hume y Kant, separaba los hechos de los valores en la Historia. El problema del estalinismo radicaba en que planteaba los sucesos como inevitables y como un avance en la Historia que no podía ser frenado de ninguna de las maneras:

So far as Stalinism is concerned, it provides a pattern which the moral critic simply inverts. The Stalinist identifies what is morally right with what is actually going to be the outcome of historical development. History is for him a sphere in which objective laws operate, laws of such a kind that the role of the individual 
human being is predetermined for him by his historical situation. The individual can accept his part and play it out more or less willingly; but he cannot rewrite the play. One is nothing in history but an actor and even one's moral judgments on historical events are only part of the action. The 'ought' of principle is swallowed up in the 'is' of history. By contrast the moral critic puts himself outside history as a spectator. He invokes his principles as valid independently of the course of historical events. Every issue is to be judged on its moral merits. The 'ought' of principle is completely external to the 'is' of history. For the Stalinist the actual course of history is the horizon of morality; that what belongs to the future is progressive is made into a necessary truth. For the moral critic the question of the course of history, of what is actually happening and the question of what ought to happen are totally independent questions ${ }^{24}$.

En un curioso precedente de lo que sería el punto central de la doctrina de Maclntyre a partir de los años ochenta, propuso que la visión griega de naturaleza humana -que no separaba hechos y valores- fuera un eje con el que entroncar la teoría de la historia de Marx:

For the Greeks the connection between the moral life and the pursuit of what men want is always preserved, even if sometimes very tenuously. The desires which the moral life is alleged to satisfy are sometimes a little curious, as for example Aristotle's conception of doing philosophy as the supreme fulfilment of human aspiration ${ }^{25}$.

Es por ello que debía rechazarse el neokantismo de Hanson y el consecuen- cialismo de Thompson. El ser y el deber ser no eran, ni mucho menos, planos que filosóficamente debieran confundirse en el seno de la teoría de la historia ${ }^{26}$. No existía ningún presupuesto deontológico que obligara a aceptar las consecuencias prácticas de la política comunista de Stalin, ni mucho menos, que hiciera creer que esa horrenda práctica era una consecuencia inevitable de la teoría de la historia de Marx. Macintyre afirmó que uno de los grandes errores que cometían Thomp-son y Hanson era no separar adecuadamente la teoría de la historia de Marx -que él consideraba una verdadera «filosofía» de la historiade la vulgarización e impostación de Stalin.

De hecho, los errores de Stalin quedaban al descubierto cuando eran comparados con las ideas de Marx. Maclntyre comentó tres cuestiones en las que el dictador soviético se apartaba deliberadamente de la obra del pensador alemán: en primer lugar, en contra del carácter supuestamente científico del estalinismo, fruto de la deriva engelsiana que he comentado antes; en segundo lugar, contra la devaluación del léxico de Marx (fundamentalmente, base y superestructura), y de las supuestas leyes que regían las relaciones entre ambas; y, por último, contra el mecanicismo y la predictibilidad científica, que nada tenía que ver con la visión de la realidad humana en la obra de Marx. Maclntyre lo expresó así:

The moral critic rejected Stalinism because it represented the historical process as automatic and as morally sovereign. And for moral values incap- 
sulated wholly in history he substituted moral values wholly detached from history. To this he added a thorough distaste for general theorising. But if we bring out as central to Marxism the kind of points which I have suggested, may not this suggest a third alternative to the moral critic, a theory which treats what emerges in history as providing us with a basis for our standards, without making the historical process morally sovereign or its progress automatic? In order to ask this question properly we ought to re-examine some of the traditional questions about human nature and morality. What is the relation between what I am, what I can be, what I want to be and what I ought to be? ${ }^{27}$

La respuesta a todo lo anterior conllevaba la necesidad de volver a Marx y dejar de lado las hipóstasis que se hubieran podido realizar de su obra. Se concluía, por tanto, que no podía aceptarse ninguna de las consecuencias de las funestas decisiones de Stalin. El dictador se había equivocado tanto en su teoría de la historia como en la defensa de un consecuencialismo científico de todos sus actos. Ninguna de las dos ideas tenía su apoyo en los textos de Marx, de modo que debían ser rechazadas de plano.

\section{El marxismo y el humanismo}

¿Existe un "humanismo» marxista? Maclntyre creía que sí. O mejor dicho, creía que existía, pero que no era el «humanismo» que los marxistas atribuían a Marx. En la segunda parte de «Notes from the moral wilderness» podemos leer las reflexiones del escocés en torno a la naturaleza humana y a la condición moral en Marx. El gran logro del filósofo de Tréveris, según MacIntyre, era el de haber sido capaz de «historizar» al hombre, es decir, explicar la filosofía de la historia humana.

Según el escocés, Marx había logrado dar una explicación de la Historia de la humanidad a partir de los límites del hombre. En una vía intermedia entre el pesimismo hobbesiano y el optimismo de Diderot, Marx fue capaz de explicar la realidad humana de una forma objetiva: a saber, como la lucha de los trabajadores para transformar el mundo ${ }^{28}$.

The fundamental answer to this is the whole Marxist theory of class-struggle. To have set the problem properly I ought to have set those changes in the moral consciousness about which I have written in their real, material context. The rift between our conception of morality and our conception of desire will never be overcome until the rift between morality and desire is overcome in action. But since we are already on the margin of the transition that will heal that breach, we can see in outline at any rate how the two may come together in consciousness. At this point the crucial concept for Marxists is their concept of human nature, a concept which has to be at the centre of any discussion of moral theory. For it is in terms of this concept alone that morality and desire can come together once more. How this is so can be seen if beside the sketchy histories of morality and desire I have given, I place an equally sketchy account of the emergence of this concept ${ }^{29}$. 
Por otra parte, el estalinismo representaba un importante error conceptual y una subversión del marxismo, dos problemas que lo hermanaban con el capitalismo. En la última parte de su artículo, Maclntyre subrayó los vínculos del estalinismo y del capitalismo, que se asemejaban por su falta de solidaridad. Este rasgo moral era lo que diferenciaba al «humanismo» de Marx respecto de los antihumanismos encarnados en el capitalismo liberal y en el estalinismo. Éstos se caracterizaban por escoger los valores, mientras que Marx los descubría en el seno de la Historia.

As against the Stalinist it is an assertion of moral absolutes; as against the liberal critic of Stalinism it is an assertion of desire and of history. To begin with the contrast with the liberal. The liberal sees himself as choosing his values. The Marxist sees himself as discovering them. He discovers them as he rediscovers fundamental human desire; this is a discovery he can only make in company with others. The ideal of human solidarity, expressed in the working-class movement, only has point because of the fact of human solidarity which comes to light in the discovery of what we want. So the Marxist never speaks morally just for himself. He speaks in the name of whole historical development, in the name of a human nature which is violated by exploitation and its accompanying evils. The man who cuts himself off from other people (and this has no content unless we realise that the vast mass of other people is the working class) says at first " I want' and then just ' want'. His 'I ought' is the most tremulous of moral utterances. For it represents nothing but his own choice. So the liberal moral critic of Stalinism isolates himself, makes his utterance unintelligible and has no defence against the patterns of conformism which his society seeks at every point to enforce upon him $^{30}$.

En el marco del divorcio entre is y ought, tanto capitalistas como comunistas no aceptaban la versión de Marx, que unía ambas perspectivas en una narración de la Historia de la humanidad. Al final, tanto estalinistas como liberales se quedaban sólo con uno de ambos planos, y daban una explicación insuficiente de la naturaleza humana. El humanismo de Marx no era el de los marxistas, sino que se encontraba en el logro intelectual de haber construido una Filosofía de la Historia en la que se explicaba la evolución de la humanidad en términos de conflicto de clase ${ }^{31}$.

The concept of human nature is therefore what binds together the Marxist view of history and Communist morality. What it teaches is in part that the liberal moral critic is the one person who has no right to criticise Stalinism. The separation of morality from history, from desire discovered through the discovery of that common human nature which history shows as emerging, leaves morality without any basis. But this is not a logical necessity for morality, as the liberal would have it. For we can depict a moral alternative which is not without any basis. The liberal critic may speak against Stalinism; but he speaks for no-one but himself and his choices. We saw the fragility of his position at the outset; we can now see why it is fragile. Furthermore we can now see more clearly what the 
liberal critic and the Stalinist have in common ${ }^{32}$.

Así pues, Maclntyre se encontraba en las antípodas del capitalismo y del estalinismo. En el seno de los debates la New Left, sin embargo, no se quedó solamente con la defensa hermenéutica de Marx, sino que avanzó, al compás de este movimiento, a la búsqueda de otros estudiosos contemporáneos. Descartado Stalin, debía buscar otro intérprete de Marx que pudiera, a la vez, ser un referente en el orden teórico y en la práctica política. Dicho en términos macintyreianos: debía encontrar un verdadero «marxista», que no separara is y ought.

La gran mayoría de sus compañeros en la aventura de la New Left, una vez expresado su malestar con el estalinismo, se mostraron cercanos a la órbita trostkista que, por su carácter algo más teórico y utópico, se adecuaba bien a sus pretensiones. Trotsky era un autor que, sin embargo, parecía excesivamente especulativo, y no tenía una dimensión tan historicista como utópica. Aún así, Maclntyre acabó -a la postre- en un trostkismo militante, como el resto de sus compañeros. Antes, no obstante, hizo un excurso leninista, para interesarse por las posibles formas de articulación de un socialismo teórico y práctico que pudiera dar una solución distinta a la crisis humanista del marxismo político.

En el año 1959, MacIntyre estudió a fondo la obra de Lenin, a la vez que se unió a la Socialist Labour League (SLL), un movimiento trotskista en el seno del Partido Laborista. Se trató del año de mayor militancia política del joven
Maclntyre, que duraría hasta 1960, cuando rompió con todo lo anterior y se vinculó a la Internacional Socialista, como veremos más adelante ${ }^{33}$.

Quedémonos por un momento en el estudio de Lenin. El teórico de la Revolución rusa había intentado justificar teóricamente su acción política, cuyos valores quedaban insertos en la praxis. Lenin, por tanto, tenía cierto interés para Maclntyre, por no haber separado la teoría de la práctica. En un panfleto titulado «What is Marxist Theory for? ${ }^{34}$ », el escocés, en tanto que filósofo metido a activista, esbozó una apología del marxismo leninista, basada en la explicación de los tópicos manidos del marxismo antiestalinista. No es ésta, ni mucho menos, la mayor contribución de Maclntyre al marxismo, pero tiene cierta importancia por dos razones: por el esbozo de un marxismo leninista y por la presentación de un leninismo humanista.

En este escrito no aparecen ni el objetivismo determinista ni el subjetivismo de Lukács. La Historia se encontraba supeditada a la clase obrera y a la creación de una conciencia de clase a través de la cual ésta pudiera creer en sus posibilidades. Para ello debían existir unos intelectuales que guiaran a las masas (poniendo a la New Left como ejemplo) y unos obreros que lucharan en contra del capitalismo. En un alarde de maniqueísmo, Maclntyre distinguió entre la «buena» y la «mala» teoría. La mala era, cómo no, la de Stalin, y la buena, la que él proponía, basada en el leninismo ${ }^{35}$.

Naturalmente, el leninismo representaba la opción más intelectual del marxis- 
mo, y estaba basada, tal y como lo recreó Maclntyre, en la función de los intelectuales como educadores de las masas obreras y en la revolución global, a la que se oponía la revolución en un solo país o el socialismo por etapas de Stalin. El escrito, bañado también de trostkismo, acababa llamando a la revolución.

De hecho, en los meses siguientes, Maclntyre se mostró muy comprometido con esta actividad divulgadora, como lo demuestran dos escritos, de una calidad sólo sensiblemente superior al panfleto anterior: "From MacDonald to Gaitskell ${ }^{36}$ » $y$ «Comunism and British Intelectuals ${ }^{37} »$. El primero es una apología del socialismo que concluye con la necesidad de que el Partido Laborista debía radicalizar su opción izquierdista, mientras que el segundo es una alocución radiada en la que Maclntyre hizo la recensión de un libro, repitiendo los mismos tópicos del leninismo humanista y de la imperiosa necesidad de incorporarlos al SLL.

\section{Del humanismo a la revolución}

Al cabo de dos meses, en marzo de 1960, Maclntyre publicó el artículo "Freedom and Revolution ${ }^{38}$ », uno de sus trabajos más importantes sobre el marxismo. En él, el escocés dio cuenta de las principales inquietudes: la necesidad de conjugar teoría y praxis y la de articular una teoría trotskista de la revolución que, sin embargo, respetara el legado de Lenin.

El problema de la conjunción de la libertad y de la revolución exigía una so- lución de carácter humanista que volviera a poner sobre el tapete la cuestión de la historia. La libertad enlazaba nuevamente la realidad antropológica con la dimensión histórica, de manera que Maclntyre tenía que poner orden en el entramado conceptual que manejaba.

\section{3.l. Algunos antecedentes}

El tema de la revolución era uno de los puntales de la obra de Marx. Sin embargo, la hermenéutica sobre las condiciones de esa revolución era uno de los temas más controvertidos del legado marxista. He dicho en el primer apartado que dejaba de considerar algunos escritos del año 1958. Uno de ellos era una recensión, titulada «The algebra of revolution», cuyas bases sirven ahora para entender el planteamiento de la revolución en los años sesenta.

Esta recensión, escrita entre Marxism: An interpretation y «Freedom and Revolution» permite mostrar la continuidad de planteamiento entre ambos escritos. En esencia, «The algebra of revolution $^{39}$ » daba cuenta de un libro de Raya Dunayevskaya -la introductora del marxismo humanista en los EEUU- en el que la autora mostraba las raíces hegelianas de la revolución, y argumentaba que toda la línea de Marx a Lenin bebía de ellas. De hecho, ese enlace se encuentra entre los Manuscritos de Economía y de Filosofía y las Anotaciones filosóficas de Lenin.

Dunayevskaya fue, en su momento, la secretaria de Trotsky y pudo leer de primera mano la obra manuscrita de los grandes autores de la tradición marxista. Maclntyre alabó la lectura directa de 
las fuentes por dos motivos: por la actividad hermenéutica que necesitaba toda teoría basada sobre las fuentes de Marx, de Lenin o de Trotsky (que distinguía muy bien cuál era la aportación de cada uno, a la vez que las diferenciaba de las de los comentaristas) y por la articulación de una línea Hegel-Marx-Lenin, en la que, si bien existían importantes diferencias teóricas, se podían seguir ciertas continuidades valiosas.

Quizás las ideas más meritorias de esta tradición eran las de la libertad y de la revolución que, exentas del mecanicismo de Engels, permitían una articulación humanista de la teoría de la revolución. De hecho, es a partir de la libertad y de la revolución cuando puede empezar a hablarse de un humanismo marxista que, a su vez, estuviera ligado al problema histórico de la naturaleza humana. Con ello quiero mostrar que en la obra de Maclntyre existe una reflexión constante sobre la revolución y la libertad, y que hay una unidad en su formación marxista. De hecho, si se leen paralelamente Marxism: An interpretation y los escritos de 1960, se notan los vínculos permanentes, que he querido enfatizar mediante el estudio de la recensión de 1958.

\section{2. «Freedom and Revolution»}

Con este artículo Maclntyre regresaba a Hegel y a algunas ideas expresadas a principios de la década de los cincuenta. La dimensión hermenéutica de la obra de Marx, vista entre la de Lenin y de Hegel, adoptaba un prisma más conflictivo al hermanarse con el trotskismo más radical ${ }^{40}$.
La dimensión antropológica quedaba enfatizada con el estudio de la libertad como «esencia del hombre», siguiendo la filosofía de Hegel. La argumentación de Maclntyre respondía a la lógica siguiente: si la libertad es la esencia del hombre, la Historia no puede predeterminar los logros de la libertad humana, por lo que el capitalismo debe ser visto como una negación de la libertad.

The paradox of bourgeois society is that it at one hand and the same time contains both the promise of greatly enlarged and the denial of that freedom. In two directions, capitalism enlarges freedom by destroying bonds and limitations. It transforms nature and ensures an effective human domination of nature ${ }^{41}$.

El sentido de la libertad es siempre colectivo, porque la libertad individual es capitalista. Esto lleva a que la libertad deba desembocar necesariamente en la revolución, que es la oposición de la colectividad frente a la individualidad y al individualismo.

The individual then cannot win his freedom by asserting himself against society; and he cannot win it through capitalist society. To be free is only possible in some new form of society which makes a radical break with the various oppressions of capitalism. Thus the topic of freedom is also the topic of revolution ${ }^{42}$.

Hasta aquí no existen grandes cambios entre 1953 y 1960. Sin embargo, en la parte final, Maclntyre escribió una crítica feroz contra los partidos políticos -sin excepciones- como cercenadores de la libertad. La verdadera revolución no podía hacerse a través de la demo- 
cracia parlamentaria y, mucho menos, a través de los partidos políticos, que monopolizaban la opinión y cercenaban la libertad. La revolución debía hacerse al margen del capitalismo democrático.

The road to freedom is the road out of what we are; so to represent what we are Hill not help us. The rise to parliamentary fame is made up one particular social ladder; the controllers of the parties who monopolise electoral discussion move along the same grooves. To break with this society, and to realise their potentialities men will have to break with parliament, too $^{43}$.

Este artículo resultó, evidentemente, de difícil digestión para la SLL, y cayó como una bomba en el Partido Laborista. Para tranquilizar los ánimos de unos y otros, Maclntyre escribió una carta en la que manifestaba su «adhesión intelectual» a la $S L L^{44}$. De poco le sirvió la adhesión, pues al cabo de unos meses fue expulsado por contravenir la tendencia del partido ${ }^{45}$.

\subsection{La vía hacia la revolución.}

Maclntyre había desarrollado, desde muy joven, una gran independencia que le sirvió para no permanecer ligado a ninguna institución ni a ninguna ideología concreta. Sin embargo, la SLL le expulsó por su voz disidente, sin que, de facto, hubiera ninguna razón para hacerlo. El escocés no se había visto completamente representado por ninguna teoría marxista y, mucho menos, por ninguna praxis. Sin embargo, los diferentes partidos en los que militó le fueron apartando cada vez más, a causa de sus ideas incómodas y poco acomodaticias.
Cuando fue expulsado de la $S L L$ no vio razones para abandonar el trotskismo, y se integró en la órbita de la Cuarta Internacional, siguiendo las ideas del teórico ruso. Sin embargo, algo había cambiado con respecto a principios de los años cincuenta: cada vez se había ido diluyendo más el elemento cristiano. Si en Marxism: An Interpretation se daba un equilibrio entre los elementos marxistas y los cristianos, en los años sucesivos todos los puntos cristianos fueron perdiendo fuerza, mientras que ganaba en vigor la secularización hegeliana.

De hecho, en el último artículo que escribió bajo la órbita de la $S L L$, titulado "Breaking the chains of Reason ${ }^{46}$ ", plantea ya una lectura de Hegel completamente secularizada. Si en 1953 la obra de Hegel era el puente ideal para recoger el caudal cristiano que el siglo XVIII no había sabido aprovechar, en 1960 era el único punto de partida posible para dar sentido a la sociedad del momento, como secularización del cristianismo ${ }^{47}$.

Y, en efecto, en el artículo permaneció la teoría de la historia antiestalinista, pero ya sin elemento escatológico. El humanismo de Hegel no era un filtro secularizador para la historia cristiana, sino la secularización misma del cristianismo. Si en Hegel se llegó al culmen de la historia del espíritu, con Marx se inició el tiempo de la revolución, donde la promesa no dependía del cumplimiento de lo prometido, sino de que la humanidad llevara a cabo la revolución permanente.

Maclntyre se planteó el problema sociológico de la revolución y atacó a Popper que había criticado al marxismo. El vie- 
nés consideraba, siguiendo la línea de Engels y Kautsky, que el marxismo era una ideología meramente mecanicista. En defensa del historicismo y del humanismo de Marx, el escocés escribió:

«Then Marx asks what the limiting factors upon human agency are in every age and finds these in basic economic relationships which are built into particular modes of production. Human history is the successive liberation of possibility as economic limitation of this kind is removed. In each age, the economic relationships mean that the rules in accordance with which social and economic life are carried on are different and differ with the mode of production. In each age, the character of the rules is determined by the relationships between men which are involved in that particular mode of production, and these relationships are not between individuals but between groupings of men, who are united by their common economic and social role, and divided from other groupings by the antagonisms of economic and social interest. So, 'all history is the history of class struggle'» ${ }^{48}$.

En el artículo, Maclntyre recalcó nuevamente el error en el que caían los teóricos de las ciencias sociales, una cuestión que, como puede verse, era ya el tópico del pensamiento del escocés: separación entre libertad y razón, y entre conocimiento y razón. Las teorías sociológicas de Wright Mills y de Parsons incurrían en este gran error del cientifismo moderno:

«Either men can discern the laws which govern social development or they cannot. If they can, then they must avow that their own behaviour is subject to these laws and consequently they must admit that they have discovered themselves to be not agents, but victims, part of a social process which occurs independently of human mind, feeling and will. If they cannot discern such laws, then they are necessarily helpless, for they have no instruments of change at their hands. So in any case human agency is bound to be ineffective. Of course, so far as smallscale changes are concerned, it may be otherwise. All sociologists leave room for reformist manoeuvre ${ }^{49}$ ».

Contra Popper y la apatía de los sociólogos, Maclntyre defendió su modelo, basado en la crítica de la escisión del sujeto en la llustración que, al parecer, había afectado a todas las esferas del saber.

"The important characteristic of this dilemma is that it separates understanding and action. Understanding and the lack of it are both a condition of inaction. At the heart of the concept of explanation there is the insight that we should not ever be in a position to assert that one event is the cause of another, unless we could produce the second event by means of the first and avert the second event by averting the first. Unless our activity was effective in bringing about changes we could not give causal explanations should underpin a thesis which culminates in the conclusion that our activity must necessarily be impo-tent ${ }^{50}$ ».

Siguiendo la línea leninista, Maclntyre ahondó en la teorización acerca de la responsabilidad de los intelectuales en la revolución ${ }^{51}$. Existían varios caminos, la mayoría de los cuales conducían al 
error. Por ejemplo, el ya citado de Popper, que mediante falsas dicotomías hacía creer al público que el liberalismo era inevitable. Otro de los errores que recalcó MacIntyre era el propio del «intelectual del partido", como era Lukács, a quien consideraba un pensador ofuscado por una realidad que no sabía denunciar ${ }^{52}$.

No cabían, pues, las opciones erróneas. MacIntyre anunció la única dicotomía posible: o Keynes o Trotsky. El primero representaba el orden establecido, el liberalismo, la atomización, la burguesía: lo que desde la filosofía moderna se ha denominado la razón: el calculus ${ }^{53}$. MacIntyre desechaba esa razón burguesa y, a ella, le contraponía el arquetipo de la revolución, encarnado en Trotsky.

"Two images have been with me throughout the writing of this essay. Between them they seem to show the alternative paths for the intellectual. The one is J. M. Keynes, the other of Leon Trotsky. Both were obviously men of attractive personality and great natural gifts. The one the intellectual guardian of the established order, providing new policies and theories of manipulation to keep society in what he took to be economic trim, and making a personal fortune in the process. The other, outcast as a revolutionary from Russia both under the Tsar and under Stalin, providing throughout his life a defence of human activity, of the powers of conscious and rational human effort. I think of them at the end, Keynes with his peerage, Trotsky with an icepick in his skull. These are the twin lives between intellectual choice in our society lies» ${ }^{54}$.
Frente a la razón, MacIntyre contraponía la acción. Lo importante eran, como hemos visto antes, las razones para la acción del hombre en la Historia. El hombre es capaz de cambiar la Historia y abrirse hacia la revolución: para ello no se requiere la razón burguesa calculadora, sino la razón que conduzca a la acción emancipatoria; una razón que rompa las cadenas de la falsa razón burguesa -que se hermana con el utilitarismo y el mecanicismo, tanto liberal como stalinista- para pasar a la acción revolucionaria.

\subsection{La Internacional socialista y la ruptura con el cristianismo}

El escocés, a diferencia de los compañeros de militancia que se han visto en las páginas precedentes, entró a partir de 1960 en una época que podríamos denominar de «desencanto», y sus escritos fueron cada vez menos «comprometidos».

El desencanto se encaminó fundamentalmente en dos direcciones: en los partidos políticos y en el cristianismo. Si los primeros representaban la colectividad, el segundo encarnaba los ideales de fraternidad en ésta. Sin embargo, ambos proyectos resultaban fracasados por su incapacidad de dar sentido epistemológico y moral al hombre. MacIntyre dejó el cristianismo, mostrando su lado más perplejo ${ }^{55}$.

The history of Marxism over the past years is so defaced by crimes and betrayals that anyone who is not yet disillusioned with Marxism is unlikely to be so in the near future. Marxists will remain few in num- 
ber. Christians are much more nu-merous and this fact alone makes it probable that the very small traffic between the two doctrines will be largely in one way ${ }^{56}$.

Su marxismo poco a poco fue apagándose, pero no su apego a la obra de Karl Marx. Puede decirse que el compromiso político de Maclntyre, al contrario que el de Thompson o Taylor, se acabó en 1960. A partir de ese momento, el escocés siguió ahondando en el problema ético y en la manera de unir las razones para la acción con una teoría moral. Su paso por la Internacional Socialista fue breve y, como casi todo en el joven Maclntyre, muy heterodoxo. Este tema, sin embargo, puede ser objeto ya de otro escrito.

\section{Conclusiones}

En este trabajo he tratado una cuestión poco conocida de la obra de Maclntyre, circunscrita a los años 1958-1960. Tres son los grandes debates intelectuales de la izquierda de la época: el humanismo, la teoría de la historia y la revolución. En una perspectiva algo mayor, se podría ver cómo el marxismo de Maclntyre se fue diluyendo completamente hacia 1970, quedando incólume su admiración por Marx. Durante la década de los sesenta, su marxismo fue una llama que iba consumiéndose, Ilena de contradicciones. Si el marxismo se fue consumiendo, a partir de finales de los años sesenta regresaron las preguntas sobre el cristianismo.

Los elementos perennes del pensamiento de Maclntyre fueron, como se ha podido ver: la necesidad de superar la esci- sión entre hechos y valores, y la de articular una teoría y una práctica que dieran sentido al ser humano y a la Historia. El escocés jamás renunció a la racionalidad y a la historicidad de sus pretensiones intelectuales. Cuando quiso «romper» las cadenas de la razón, no se refiere al logos griego, que une razón y acción, sino a las cadenas de la razón escindida, víctima de la atomización liberal y del capitalismo económico.

En esta época puede verse, si se quiere, la fase más embrionaria de un posible pensamiento grupal, que derivará en las comunidades aristotélicas en los años ochenta. Sin embargo, lo importante es que Maclntyre siempre ha sido un filósofo de la sociedad, y en aquel momento entendía que era necesario tomar prestado el legado de Hegel y de Marx para justificar las razones para la acción.

Por otra parte, que el marxismo de Maclntyre estuviera ligado al cristianismo era una necesidad recíproca: uno no era sino el complemento del otro. Si su marxismo podía tener, en su praxis política, una deriva engelsiana, ahí estaba el cristianismo para corregir el mecanicismo en pos de un humanismo. Si la Historia en el marxismo quedaba en lo concreto, el cristianismo ponía lo sobrenatural y lo escatológico. En definitiva, si existía una revolución primitiva, ésa era la cristiana. Por otra parte, el marxismo era el «nieto» del cristianismo, que espoleaba a su abuelo que progresivamente se había aburguesado y acomodado. Frente a la Parusía, el marxismo obligaba al cristianismo a construir un Reino de los Cielos en la Tierra, a partir de la revolución. 
De esta forma, MacIntyre construyó un eje gigantesco Cristianismo-Hegel-MarxLenin-Trotsky, que tenía los pies de barro. La depuración del cristianismo y la del marxismo fue consumiendo la vehemente esperanza de Maclntyre. Quedaron incólumes los iniciadores, pero toda la tradición se reveló baldía. Si valía la pena continuar con el cristianismo y con el marxismo era sólo por cuanto oponían a sus enemigos, tanto en casa como fuera de ella: el liberalismo y el comunismo.
Éstas son algunas de las conclusiones de una época y de un pensador que aún necesitan ser analizados con mayor profundidad. De momento, estas líneas son primeros planos de un terreno casi virgen para el estudio. Quedan todavía por analizar las fecundas relaciones que, en la obra de MacIntyre, tienen el marxismo y la filosofía de la religión o el psicoanálisis en esta misma época. Todo ello sigue siendo un territorio inexplorado, a cuya cartografía estas páginas han querido contribuir sucintamente.

\section{Notas}

${ }^{1}$ Lo mejor que puede leerse en español sobre el joven Maclntyre es el libro de F. J. de la Torre Díaz: Alasdair Maclntyre, ¿Un crítico del liberalismo?, Madrid, Dykinson, 2005, fundamentalmente las pp. 19 y ss.

${ }^{2}$ Citaré por la versión Marxism \& Christianity, segunda versión, London, Duckworth, 1995.

${ }^{3}$ Véase P. Blackledge \& N. Davidson (eds.) Alasdair Maclntyre's Early Marxist Writings: Essays and Articles 1953-1974, Leiden: Brill, 2008, pp. xiii y ss.

${ }^{4}$ Véase A. Flew y A. Maclntyre (eds.): New essays in Philosophical Theology, New York, Macmillan, 1973, [Primera edición de 1955].

${ }^{5}$ Un rápido resumen puede verse en $\mathrm{E}$. Perreau-Saussine: Alasdair Maclntyre: Une biographie intellectuelle, París, PUF, 2005, particularmente, el capítulo 1: «Politique: des existences appauvries».

${ }^{6}$ Marxism \& Christianity, cit. p. 99.

7 Marxism \& Christianity, cit. p. 100-101.

8 Véase fundamentalmente: "Hume on 'Is' and 'Ought'» Philosophical Review, 68, 1959, 451-68. reimpreso en Against the SelfImages of the Age: Essays on Ideology and Philosophy, (University of Notre Dame Press, 1978) pp. 109-24. «Ought» en el mismo volumen, pp. 136-56.

9 T. D'Andrea: Tradition, Rationality, and Virtue: The Thought of Alasdair Maclntyre,
London, Ashgate Publishing, 2006, pp. 8894.

${ }^{10}$ P. Blackledge: «Freedom, Desire and Revolution: Alasdair Maclntyre's Early Marxist Ethics» History of Political Thought Vol. XXVI, No. 4, 2005. «Unfortunately, while MacIntyre was at this time both a practising Christian and a member of the Communist Party, this interpretation of Marxism failed to provoke much interest in either Communist or Christian circles. It was the emergence of the New Left three years later that provided MacIntyre both with an audience for his ideas and a practical source of inspiration from which he deepened these ideas. Therefore, while it is true to say, as does McMylor, that Maclntyre's early work prefigured many of the themes that dominated New Left thinking, it is also important to remember that, without the New Left, Maclntyre's project would have remained abstract and disconnected from practical politics», p. 700.

11 Marxism \& Christianity, cit. p. 7 y ss.

12 Universities and Left Review, 4, Summer 1958, 72-3

13 Universities and Left Review, 5, Autumn 1958, 79-80.

14 Para una buena contextualización de este escrito en la obra de Thompson, véase B. D. Palmer: «Homage to Edward Thompson» en Labour/Le Travail, Parte I, pp. 14-16. 
15 «Socialist humanism: An Epistle to the Philistines» en The New Reasoner, 1957, pp. 105-143.

16 P. Blackledge: Reflections on the Marxist theory of history, Manchester University Press, p. 179 y ss.

${ }^{17}$ E.P. Thompson, 'Socialist Humanism', The New Reasoner, 1 (Summer 1957), p.105.

${ }^{18}$ Véase P. Blackledge, «Freedom, Desire and Revolution: Alasdair Maclntyre's Early Marxist Ethics» op. cit., p.701. «However, in contrast to this characterization of the Soviet system as being at once socialist while yet morally unpalatable, elsewhere he insisted that the «end» of Communism is not a «political» end, but a human end'. This formulation suggested a tremendous gap between the human ends of the Soviet experiment and the inhuman means through which these ends were, at least partially, being realized. So while Thompson implied that a plurality of means could be utilized to achieve the end of communism, he was aware that these means were not morally equivalent. Concretely, in the Soviet case, he argued that the flaws of the Stalinist system could best be understood as a consequence of the inadequate model of Marxism that had guided the Bolsheviks. He claimed they had embraced a mechanical interpretation of Marx's base/superstructure metaphor such that agency, in the form of the conscious activity of the masses, was increasingly disregarded, only to find expression through the monolithic party which became the guardian of true socialist consciousness. Following this, the 'immorality' of replacing the actions of real individual with those of cardboard abstractions became 'embodied in institutional form in the rigid forms of «democratic centralism»". Consequently, Thompson's moral critique of Stalinism involved a call both for a more flexible interpretation of Marx's theory of history and a rejection of the Leninist form of political organization».

19 Sobre este debate puede leerse una síntesis muy detallada en P. Blackledge: «Morality and Revolution: Ethical Debates in the British New Left» en Critique, 35, 2007, pp. 211-228.
20 «An open letter to Edward Thompson» en The New Reasoner, 9, 1957, pp. 98-107.

21 Véase P. Blackledge: "Morality and Revolution: Ethical Debates in the British New Left», cit. p. 218.

22 «An open letter to Edward Thompson», p. 81. [Los subrayados aparecen en el original].

23 "Marxism and humanism», en The New Reasoner, 1957, pp.105-143.

24 «Notes from the moral wilderness» (primera parte), The New Reasoner, Winter 1958-59, p. 91.

25 «Notes from the moral wilderness» (segunda parte), The New Reasoner, Spring 1959, p.91 .

26 «Notes from the moral wilderness» (primera parte), The New Reasoner, Winter 1958-59, pp. 90-96.

27 «Notes from the moral wilderness» (primera parte), The New Reasoner, Winter 1958-59, p. 96.

28 «Notes from the moral wilderness» (segunda parte), The New Reasoner, Spring 1959, p.92.

29 "Notes from the moral wilderness» (segunda parte), The New Reasoner, Spring 1959, p. 93.

30 "Notes from the moral wilderness» (segunda parte), The New Reasoner, Spring 1959, p. 96.

${ }^{31}$ Véase P. Blackledge: «Freedom, Desire and Revolution: Alasdair Maclntyre's Early Marxist Ethics» op. cit., p. 703 y ss.

32 "Notes from the moral wilderness» (segunda parte), The New Reasoner, Spring 1959, p. 97.

33 Véase P. Blackledge: "Morality and Revolution: Ethical Debates in the British New Left», cit. "Concretely, Maclntyre's move from the orthodox Trotskyism of the SLL to the heterodox revolutionary politics of IS can be read as a logical continuation of the critique he made of the political style of the SLL leadership while still a member of that organisation. In 1959, Maclntyre engaged Cliff Slaughter on the pages of Labour Review, the SLL's monthly theoretical magazine, regarding the issue of the SLL's relationship 
to the broader New Left milieu. Slaughter argued that it was incumbent upon the SLL to 'state sharply where we differ on basic questions of theory and method' from the New Left. He then proceeded to trace out and criticise the arguments regarding the nature of social class in the modern world as articulated by a number of important New Left thinkers; principally, Dorothy Thompson, Charles Taylor and Stuart Hall.», p. 225.

${ }^{34}$ Newsletter, v. 3, no 121, Octubre 1959, p. 289.

35 Ibidem.

${ }^{36}$ Socialist Labour League Pamphlet, London, 1960.

37 The Listener, 7 de enero de 1960. [Originalmente procede de un programa de la radio de la BBC].

38 Labour Review, Feb./Mar. 1960, 19-24.

39 Universities and Left Review, 5 (Otoño, 1958), 79-80.

40 «Freedom, Desire and Revolution: Alasdair Maclntyre's Early Marxist Ethics», op. cit. p. 710.

41 «Freedom and revolution» en p. 126.

42 «Freedom and revolution» en p. 130.

43 «Freedom and revolution», p. 131.

44 "Letter» en The Listener, 17 de Marzo de 1960, p. 500.

${ }^{45}$ Alasdair Maclntyre's Early Marxist Writings: Essays and Articles 1953-1974, p. xxx.

46 "Breaking the chains of Reason», cito por P. Blackledge \& N. Davidson (eds.) Alasdair Maclntyre's Early Marxist Writings: Essays and Articles 1953-1974, pp. 135-166.
47 T. D. D'Andrea: Tradition, Rationality, and Virtue: The Thought of Alasdair Maclntyre, cit. pp. 101-104.

48 «Breaking the chains of Reason», p. 151.

49 «Breaking the chains of Reason», p. 156.

50 «Breaking the chains of Reason», p. 156.

51 "In his essay 'Breaking the Chains of Reason', he set himself the task of uncovering the intellectual culture that reinforced political apathy by denigrating the very concept of commitment. Pointing out that at the cusp of the modern era intellectuals were wont to identify themselves as radicals, Maclntyre noted that the dominant reason given by contemporary intellectuals to excuse their own lack of political commitment was to note the apathy of the workers», p. 707.

52 «Breaking the chains of Reason», p. 163.

53 F. Martínez Marzoa: Historia de la Filosofía, tomo II, Madrid, Istmo, 1994, véanse esencialmente los capítulos dedicados a los orígenes de la Modernidad, pp. 25-99.

54 «Breaking the chains of Reason», p. 166.

55 Las palabras que precedían al artículo «Marxists and Christians» eran las siguientes: "Alasdair Maclntyre sums up his own standpoint for us: «Was a Christian. Am not. It is less misleading when asked if I am a Marxist to say 'yes? Rather than 'no'. But other Marxists have been known to say 'no'» en Blackledge y Davidson (2008), p. 179, $\mathrm{n} 1$.

56 "Marxists and Christians», cito por P. Blackledge \& N. Davidson (eds.) Alasdair MacIntyre's Early Marxist Writings: Essays and Articles 1953-1974, p. 186. 